\title{
Van kerken en dorpen
}

Jacobine Gelderloos*

\section{Summary}

The relation between church and village is shifting due to processes of de-churching, regionalisation, cooperation, and mobilisation. In the past a village often consisted of various churches, now it is the other way around: a church congregation consists of several villages. In this article I want to investigate what ecclesiological questions arise from this changing relation between church and village. First, I describe the processes of regionalisation and cooperation in the last decades and the consequences for being church in the countryside. Secondly, I explore a couple of developments that shed light on how the village church in the future might look like. The combination of cooperation processes and new forms of church lead to a mixed economy and raise ecclesiological questions, such as how to remain present as a church in several village communities? David Walker, Michael Moynagh and Pete Ward provide useful insights to understand rural ecclesiology.

\section{Inleiding}

De ontkerkelijking heeft ervoor gezorgd dat kerkelijke gemeenschappen krimpen. In sommige plattelandsregio's wordt dat proces nog eens versterkt door toenemende vergrijzing en bevolkingskrimp. De gevolgen daarvan zijn duidelijk zichtbaar: er gaan minder mensen naar de kerk, er zijn minder financiële middelen, waardoor de predikantsplaatsen kleiner worden en kerkgebouwen afgestoten worden. Er zijn minder mensen die in de kerkenraad en commissies willen, waardoor het steeds lastiger wordt om het kerkelijk leven gaande te houden. In elk geval in de vorm zoals we dat lange tijd gekend hebben (Gelderloos 2018a).

Dit is het dominante kerkbeeld op dit moment en dat is ook zeker de realiteit in veel (dorps)kerken, maar het is niet het hele verhaal. Tijdens mijn promotieonderzoek bij de Protestantse Theologische Universiteit heb ik het dorpskerkelijk leven in kaart gebracht in twee Protestantse gemeenten: de

* Jacobine Gelderloos is werkzaam als verbindend specialist-projectleider Dorpskerkenbeweging (Ondersteuning Gemeenten) van de Protestantse Kerk in Nederland. Daarnaast is ze als post-doc verbonden aan de Rijksuniversiteit Groningen. 
een in Asten-Someren, in het zuidoosten van de provincie Noord-Brabant, de ander in Groningen: Schildwolde-Hellum-Overschild en Noordbroek. Waar Noord-Brabant een overwegend katholieke provincie is, is Groningen de meest seculiere provincie van Nederland met een geschiedenis van kerkscheuringen. Dat betekent dat er contextuele verschillen zijn. Protestanten in Brabant zijn met name in grotere dorpen te vinden, terwijl er in Groningen tal van samenwerkingsverbanden zijn tussen dorpsgemeenschappen. In beide case studies omvatten de protestantse gemeenten meerdere dorpen. Daarmee komt de relatie tussen kerk en dorp direct ter discussie te staan. Hoe verhoud je je als kerkgemeenschap tot deze verschillende dorpen?

Niet alleen het kerkelijk leven maar ook het plattelandsleven is de afgelopen vijftig jaar ingrijpend veranderd. Door toegenomen mobiliteit, vergrijzing en demografische ontwikkelingen, schaalvergroting en veranderingen in de landbouw is de leefbaarheid op het platteland onder druk komen te staan. Het begrip leefbaarheid is daarom behulpzaam om de plattelandscontext van dorpskerken te betrekken in het onderzoek. De centrale vraag in mijn onderzoek was: hoe dragen kerken bij aan de leefbaarheid van het platteland (Gelderloos 2018a; 2018b)? Door het kerkelijk leven in de context van platteland en leefbaarheid te plaatsen kwam enerzijds naar voren dat dorpskerken meer dan alleen een religieuze functie vervullen. Kerken spelen ook een rol in het dorp als gemeenschap waar mensen naar elkaar omkijken en als ontmoetingsplek waar verschillende voorzieningen geboden worden variërend van onderhoud van de begraafplaats tot maaltijdprojecten en inzamelacties. Anderzijds is er weliswaar sprake van krimp, maar wordt ook duidelijk dat het religieuze dorpsleven zich niet beperkt tot het kerkelijk domein (Gräb 2010). Het kerkelijk leven in een netwerksamenleving blijkt een dynamisch terrein. De relatie tussen kerk en dorp is niet alleen veranderd door processen van samenwerking en regionalisering, maar ook door de differentiatie en secularisering van de samenleving. Deze ontwikkelingen hebben ertoe geleid dat niet altijd meer duidelijk is wat kerk te maken heeft met zorg, onderwijs, huisvesting en werkgelegenheid, wat leidt tot kerkelijke verlegenheid enerzijds. Anderzijds zien we religieus analfabetisme door een groeiende onbekendheid met kerk, geloof en religie (Gelderloos 2018a, 82-86).

In dit artikel wil ik onderzoeken welke ecclesiologische vragen opkomen in deze dynamiek van een verschuivende relatie tussen kerk en dorp. Hiervoor baseer ik mij in de eerste plaats op het empirische materiaal van bovengenoemde case studies uit mijn promotie-onderzoek. Deze data heb ik, in mijn rol als projectleider van de Dorpskerkenbeweging van de Protestantse Kerk in Nederland, kunnen aanvullen met de bevindingen van de dorpskerken- 
ambassadeurs, die in alle regio's van het land (protestantse) dorpskerken bezoeken en ontwikkelingen waarnemen. Ik beschrijf in paragraaf 2 hoe die relatie tussen protestantse kerken en dorpen zich de laatste decennia ontwikkeld heeft door processen van ontkerkelijking, regionalisering en samenwerking. Deze processen roepen vragen op over hoe kerkelijke gemeenten zichtbaar aanwezig kunnen zijn en blijven in het dorpsleven. In paragraaf 3 verken ik met behulp van inzichten van David Walker een aantal tendensen die zicht geven op hoe de dorpskerk van de toekomst eruit zou kunnen zien en die een tweede cluster van vragen oproepen over wat wel en niet als kerk beschouwd kan worden. Het samenspel van samenwerkingsprocessen en nieuwe vormen van kerk-zijn leiden tot een kluwen van ecclesiologische vragen. Aan de hand van ecclesiologische theorieën van David Walker, Michael Moynagh en Pete Ward probeer ik deze kluwen enigszins te ontwarren en te kijken hoe deze vragen als vertrekpunt kunnen worden genomen voor kerkzijn op het platteland in de $21^{\mathrm{e}}$ eeuw.

\section{Verschuivende relatie tussen kerk en dorp}

\section{In tijden van samenwerking}

Al vele decennia wordt geprobeerd om toekomstbestendige oplossingen te vinden voor krimpende kerkgemeenschappen. In de jaren 50 van de 20 eeuw verschenen diverse studies naar kerkelijkheid en buitenkerkelijkheid in verschillende regio's (Staverman 1954; Sennema 1959). Sinds de jaren 60 wordt beleidsmatig sterk ingezet op samenwerking, zowel in de hervormde als in de gereformeerde kerken (De Loor 1963; Van Stegeren 1966; Leene 1969). Er verschenen brochures met als titel: 'Hoe komen kerken tot nauwere samenwerking?' (Hendriks et. al. 1971). Het idee was dat een aantal zaken, zoals jeugdwerk en diaconaat, beter regionaal georganiseerd kon worden, zodat er aan massa en slagkracht gewonnen kon worden, terwijl lokaal vieringen en pastoraat doorgang zouden kunnen vinden. Ook ontstonden ideeën rond het vormen van teams van predikanten en streekgemeenten. Het beleid vanuit de landelijke kerken zette in op regionale samenwerking, maar op lokaal niveau waren kerkelijke gemeenten terughoudend. Ze wilden hun onafhankelijkheid behouden en gaven de voorkeur aan het aanstellen van een deeltijdpredikant of een kerkelijk werker (Hoogterp 1998; Broos 1998). Een veelvoorkomende situatie was dat twee of drie dorpskerken samen één predikant benoemden: combinatiegemeenten. De gemeenten bleven verder zelfstandig met een eigen kerkenraad en kerkgebouw. Zo vormden Hellum en Schildwolde 
in Groningen sinds 1967 een combinatie waardoor ze samen een predikant konden benoemen en het Brabantse Asten en Someren deelden sinds 1960 een predikant.

Vanaf de jaren 80 kwam op veel plaatsen het Samen-op-Weg proces op gang. Dit proces kwam voort vanuit een streven naar eenheid. In de praktijk betekende de samenvoeging van hervormde en gereformeerde kerkelijke gemeenten, vaak ook een - soms langdurig - fusieproces, waarin de nodige organisatorische vragen beantwoord moesten worden, zoals welk kerkgebouw afgestoten moest worden (Van der Veer 1999; Valstar 2004; Van Hierden 2010). Het Samen-op-Weg proces zag er ook overal weer anders uit. In een regio als Noord-Brabant is in veel dorpen misschien wel een hervormde kerk te vinden, maar geen gereformeerde. Dat betekende dat gereformeerden vanouds in een grotere plaats als Helmond of Eindhoven naar de kerk gingen. Toen het Samen-op-Weg proces zich ontwikkelde kozen gereformeerden er steeds vaker voor om in het dorp waar ze woonden ook naar de (voormalig) hervormde kerk te gaan. Dat betekende dat het Samen-op-Weg proces heel geleidelijk verliep. In andere regio's was het ingewikkelder en werd het proces soms ook afgebroken. Zoals in sommige Groningse dorpen, waar de effecten nog lang voelbaar waren doordat mensen elkaar gingen mijden. ${ }^{1}$

Rond 2000 groeide het besef dat een top-down benadering om streekgemeenten te vormen met een overkoepelende kerkenraad niet altijd succesvol was, omdat de schaalvergroting ertoe leidde dat mensen zich minder betrokken begonnen te voelen. Daarom werd vanuit de Protestantse Kerk in Nederland het project Samenwerking gemeenten (SAGE) opgezet. Het achterliggende idee was dat contacten en uitwisseling tussen gemeenten in clusterverband ertoe zouden leiden dat gemeenten waar nodig regionaal samen konden werken, om daardoor juist lokaal kerk in het dorp te kunnen blijven (Bruijkers 2003; Van den Akker 2003; Rienksma 2003; Vos 2011; De hand aan de ploeg 2009). Een SAGE traject kon leiden tot fusie, maar dat hoefde zeker niet. Belangrijk verschil met eerdere samenwerkingstrajecten was dat er niet altijd meer samenwerking werd gezocht met gemeenten die in geografische zin het dichtste bij lagen, maar juist op confessioneel vlak. De Groningse case study uit mijn promotieonderzoek illustreert deze situatie goed. Het Samen-op-Weg-proces tussen de gereformeerde kerk van Schildwolde en de hervormde gemeente Schildwolde-Hellum liep spaak. Een paar jaar later fuseerde de gereformeerde kerk Schildwolde met de hervormde gemeente van het naastgelegen Slochteren. Onderwijl sloten de hervormde gemeenten van Overschild en Noordbroek zich aan bij de hervormde gemeente SchildwoldeHellum. 
Het is opvallend dat in de praktisch theologische literatuur die in de laatste 20 jaar verschenen is over kerk-zijn op het platteland, grotendeels voorbij wordt gegaan aan deze processen van samenwerking en wat die betekenen voor kerk-zijn op het platteland. Ploeger en Ploeger-Grotegoed schetsen het beeld van een dorp waar mensen weinig gericht zijn op vernieuwing. Brouwer et al. benadrukken het belang van de dorpskerk voor de continuïteit en de sociale cohesie van het dorpsleven (Ploeger \& Ploeger-Grotegoed 2001; Brouwer et al. 2007). Er is echter weinig aandacht voor de ecclesiologische consequenties van de reorganisaties die hebben plaatsgevonden (Gelderloos 2018a, 98-100).

\section{Ecclesiologische consequenties}

Samenwerking is vaak nodig om voldoende financiële middelen en menskracht te vinden om het kerkelijk leven gaande te houden, maar de praktijk blijkt weerbarstig. De kans is groot dat samenwerking ten koste gaat van de zichtbaarheid van de kerk in het dorp, als er geen predikant meer woont, het kerkgebouw niet meer gebruikt wordt of slechts een paar keer per jaar en er geen kerkelijke activiteiten meer gehouden worden. Dat maakt dat mensen zich minder betrokken voelen bij de kerkgemeenschap. Daarnaast vraagt het samenvoegen van verschillende kerkelijke gemeenten ook de nodig aandacht als het gaat om gemeenschapsvorming. Mensen hebben de neiging om bijvoorbeeld bij de koffie na de dienst bij hun eigen dorpsgenoten te gaan zitten. En kinderen en tieners die elkaar niet kennen van school hebben meer tijd nodig om een band op te bouwen (Gelderloos 2018a, 286).

Een tweede gevolg van de opeenvolgende processen van samenwerking en regionalisering is dat de blik van kerkgemeenschappen naar binnen wordt gericht, doordat veel aandacht en energie besteed wordt aan organisatorische vraagstukken (De Roest \& Stoppels 2015, 64). Het is veelzeggend dat als er geschreven wordt over samenwerking van kerken, dan vooral gedoeld wordt op regionale contacten met kerken van dezelfde denominatie. Er is minder aandacht voor lokale oecumenische samenwerking en de mogelijkheden om als kerk samen te werken met lokale en regionale niet-kerkelijke organisaties. De organisatorische benadering heeft het grote risico dat voorbij gegaan wordt aan de specifieke context van een geloofsgemeenschap en het geloof, de idealen en motivatie die de geloofsgemeenschap gaande houden (De Jong 2008, 219-221). Mijn indruk is dat de vraag hoe blijven we als kerk zichtbaar aanwezig in en betrokken bij het dorpsleven en de dorpsgemeenschap weinig centraal heeft gestaan in samenwerkingsprocessen.

Er is wel een kentering gaande. Wim Beekman, tegenwoordig classispredikant in Friesland, pleitte er in 2011 voor om als kerkgemeenschap zo 
lang mogelijk kerk op het dorp te blijven, al is het maar als huisgemeente (Beekman 2011). In 2016 heeft de Synode van de Protestantse Kerk ook het voorstel aangenomen dat een gemeente na opheffing voortgezet mag worden als huisgemeente (Plaisier 2016a, 10,25,27; 2016b, 20-22, 27; Stoppels 2017). De aandacht groeit voor kerk-zijn op het dorp. In de bundel Klein en Dapper van de Protestantse Kerk worden dorpskerken in beeld gebracht die 'het vuur brandende houden' met een klein aantal kerkleden. In sommige gevallen is het Samen-op-Weg-proces afgebroken, maar gaan de kerkelijke gemeenschappen afzonderlijk of deels samenwerkend door. Soms wordt een predikant gedeeld met een andere gemeente, soms is er geen predikant en gaan leken voor in vieringen. De nadruk wordt gelegd op zichtbaar blijven in de dorpsgemeenschap door het kerkgebouw open te stellen, door vieringen te organiseren op zondagochtend, maar ook op andere momenten en door contact te zoeken met dorpsorganisaties om samen activiteiten en voorzieningen op te zetten voor het dorp. Op deze manier proberen kerken zich in te zetten voor de dorpsgemeenschap, zich te verbinden met mensen die zelden een kerk bezoeken en een antwoord te bieden op een sceptische houding ten opzichte van de kerk (Klein en dapper 2016; Mesman \& Van Dijk 2011).

De ontwikkelingen van de afgelopen jaren hebben ertoe geleid dat kerkzijn op het platteland verschillende verschijningsvormen kent, waardoor er voortdurend verschuivingen plaatsvinden in de relatie tussen kerk en dorp. Je zou kunnen zeggen dat dé dorpskerk niet meer bestaat. Waar eerder vaak meerdere kerken in een dorp te vinden waren, is het nu niet zelden andersom: een kerk bestaat uit meerdere dorpen. Vaak gaat het om twee of drie dorpen, maar er zijn ook kerkelijke gemeenten die 8 of 9 dorpen omvatten. Dat heeft praktisch de nodige consequenties: in sommige gemeenten is ervoor gekozen om de kerkdiensten afwisselend in verschillende dorpen te laten plaatsvinden. Dat betekent dat de gemeente steeds in een andere kerk samenkomt voor de zondagse kerkdienst. Het gebeurt ook wel dat één of meerdere kerkgebouwen worden afgestoten en dat het kerkelijk leven zich in één dorp concentreert. Daarnaast kunnen predikanten maar in één dorp wonen en dus niet in andere dorpen. Als de predikant überhaupt nog in een van de dorpen woont, want het gebeurt steeds vaker dat een predikant of kerkelijk werker ergens anders woont. Bijvoorbeeld omdat hij/zij twee parttime aanstellingen combineert.

De laatste tijd begint zich een nieuwe ontwikkeling af te tekenen: een dorpskerk die fuseert met een grotere plaats en daarmee een wijkkerk wordt. Dat betekent dat er verschillende manieren van kerk-zijn zich tot elkaar moeten verhouden. Hier kunnen verschillen tussen urbaan en ruraal kerk-zijn 
aan de oppervlakte komen. Zoals die verschillen ook een rol kunnen spelen in dorpen waar de bevolkingssamenstelling verandert door de komst van import. De Britse theoloog Anthony Russell beschrijft de verschillende kerkbeelden als volgt:

\begin{abstract}
"There is a basic tension between those who see the church as a focus of the village community, which attempts to give a Christian understanding and meaning to the whole life of the village, which it in a sense represents, and those who see the church as a gathering of Christians out of the community to form a distinct, self-contained organization with a degree of self-consciousness and definition. [...] The village church model sees community in terms of identification, while community in a gathered church model is seen in terms of participation" (Russell $1986,258-259)$.
\end{abstract}

Het is de vraag of in de Nederlandse context het verschil tussen ruraal en urbaan kerk-zijn zo scherp gemaakt kan worden. Maar wat wel gezegd kan worden is dat het kerkelijk leven op het platteland urbaniseert in die zin dat mensen niet vanzelfsprekend naar de kerk gaan in het dorp waar ze wonen, maar eerder geneigd zijn om zoals in de stad een kerk te zoeken waar ze zich aangesproken voelen.

Dat blijkt ook uit het ontstaan van regionale identiteitsgemeenten. Deze regionale gemeenten zijn niet ontstaan vanuit processen van samenwerking, maar het zijn kerken met een uitgesproken liturgische of theologische identiteit die mensen uit de wijde omgeving trekken. Het gaat dan om mensen die zich niet (meer) thuis voelen in hun dorpskerk of die op de een of andere manier betrokken zijn geraakt bij dergelijke geloofsgemeenschappen. Zoals in Huizinge: tijdens het Samen-op-Weg proces tussen hervormd MiddelstumHuizinge en gereformeerd Middelstum, werd voorgesteld om niet meer de kerk in Huizinge te gebruiken. De gemeenschap van Huizinge vond dat niet acceptabel en is met een team van voorgangers en een kerkmusicus voor zichzelf begonnen. Tien jaar later is het een bloeiende geloofsgemeenschap, elke zondag is de kerk goed gevuld, grotendeels met mensen die van buiten het dorp komen. Hier komen mensen vanuit alle windstreken naar Huizinge gereden, om vervolgens weer naar huis te gaan.

Zo ontstaat op zondagochtend een enigszins paradoxale situatie. Enerzijds komen mensen vanuit alle windstreken naar een dorp als Huizinge gereden. Anderzijds zijn er dorpen zoals Overschild, waar mensen op zondagochtend uitvliegen naar alle windstreken: naar de hervormde kerk in Hellum of Schildwolde, naar de vrijgemaakt gereformeerde kerk in Schildwolde, naar 
de synodaal gereformeerde kerk in Ten Post of naar de Nederlands gereformeerde kerk in Groningen. Er staat een kerkgebouw, waar soms nog diensten plaatsvinden, er wonen mensen die naar de kerk gaan, maar is er nog kerk in Overschild? De kerkgangers vormen in elk geval niet een gemeenschap.

In alle gevallen kunnen zich verschillende vragen, zowel praktisch als inhoudelijk, opdringen. Hoe zijn we kerk in het dorp? Hoe zijn we kerk voor het hele dorp als er meerdere kerkgenootschappen zijn? Hoe zijn we kerk in alle dorpen, als de kerk meerdere dorpen omvat? Hoe zijn we kerk in het dorp van en voor de kerkgangers die uitvliegen naar alle windstreken? Hoe zijn we kerk in het dorp als $80 \%$ van de kerkgangers elders woont en zij elkaar door de week niet tegenkomen in het dorpshuis, op het schoolplein of in de winkel? Het lijkt erop dat in literatuur en beleidsnotities over het algemeen weinig aandacht is geweest voor dit soort vragen, hoewel er de laatste jaren een kentering begint plaats te vinden met een 'turn to the local' (Gelderloos 2018a). Ondertussen ontwikkelt het dorpskerkelijk leven zich verder. Zowel in mijn onderzoek als in de dorpskerkenbeweging zie ik in elk geval vier ontwikkelingen waarin de mogelijke contouren zichtbaar worden van toekomstig (dorps)kerkelijk leven. In de volgende paragraaf beschrijf ik deze ontwikkelingen en welke vragen die oproepen over wat wel en niet als kerk beschouwd kan worden.

\section{Dorpskerk van de toekomst?}

Ook al is het groepje kerkgangers dat op zondagochtend in de kerk zit soms klein, toch blijkt dat een grotere kring van mensen zich verbonden voelt met de kerk, maar dat op een andere manier uit. De Britse theoloog David Walker maakt onderscheid tussen vier vormen van verbinding met kerk (modes of belonging) (Walker 2012). Mensen kunnen zich verbonden voelen met een kerk door 1 . de gemeenschap, de band die ze met mensen voelen; 2. de regelmatig terugkerende activiteiten zoals kerkdiensten, gespreksgroepen, die maken dat mensen elkaar regelmatig zien en een gedeeld verhaal opbouwen; 3 . incidentele evenementen zoals doopvieringen, huwelijken en uitvaarten, maar ook kerst, pasen en het dorpsfeest, waardoor dorpsbewoners weer eens de kerk binnenkomen en 4. de plaats van het kerkgebouw, waar vaak zowel kerkgangers als dorpsbewoners een sterke verbondenheid mee voelen. Met name evenementen en het kerkgebouw maken de kerk zichtbaarder in het dorpsleven.

Deze verschillende vormen van verbinding brengen met zich mee dat mensen ook bij meerdere kerken tegelijk betrokken kunnen zijn. In het zuiden 
van Nederland wil het nog wel eens gebeuren dat in gemengde huwelijken de aandacht verdeeld wordt tussen de katholieke en de protestantse kerk. Het kan ook zijn dat mensen vanuit een bepaalde loyaliteit met een zekere regelmaat in hun eigen dorp naar de kerk gaan, maar dat ze zich ook nog verbonden voelen met een kerkgemeenschap waar ze eerder naar toe gingen, of dat ze vanwege leeftijdsgenoten, vaak jonge gezinnen, ook naar een stadskerk gaan. En dan kan het gebeuren dat er twee dorpen verder een interessante gespreksgroep is, waar mensen soms ook wat vrijer durven praten dan in hun eigen dorp, waar ze mensen al hun hele leven kennen.

Je zou kunnen spreken van multiple ecclesial belonging: mensen voelen zich betrokken bij meerdere kerkgemeenschappen en zijn daar op verschillende manieren mee verbonden. Ze voelen bijvoorbeeld een verbondenheid met het kerkgebouw in hun dorp, met de mensen van de geloofsgemeenschap waar ze eerder naar toe gingen en worden ten slotte aangesproken door een activiteit elders in de regio. Deze vorm van kerkelijk leven is typisch voor een netwerksamenleving. Kerkgemeenschappen vervullen voor individuele gelovigen verschillende functies, spelen in op verschillende behoeften. Het nadeel is dat tijd en aandacht verdeeld moeten worden. Het voordeel is dat er informeel een haast onzichtbaar netwerk tussen kerkgemeenschappen bestaat, waarin ideeën en ervaringen gedeeld en doorgegeven kunnen worden. De vraag is alleen of dat voldoende gezien en gewaardeerd wordt, of dat mensen er vooral op worden aangekeken dat ze niet volledig beschikbaar zijn (Gelderloos 2018a, 302).

Een tweede interessante ontwikkeling zijn pioniersplekken, 'nieuwe vormen van kerk-zijn voor mensen die niet (meer) naar een kerk gaan’ (https:// www.protestantsekerk.nl/thema/missionair-werk/faq/). Pioniersplekken zijn weliswaar voornamelijk in stedelijke context te vinden, maar ook op het platteland ontwikkelen zich pioniersplekken. Zoals Nijkleaster in Jorwerd, of Zinvol Zijpe, waar een predikant/pionier is aangesteld (https://nijkleaster.frl/; http://www.zinvolzijpe.nl/). In Zijpe wordt de pioniersplek beschouwd als een mogelijke doorstart voor de dorpskerk, daarmee heeft de pioniersplek een natuurlijk draagvlak. Dat is niet altijd vanzelfsprekend. Een van de belemmeringen voor het ontstaan van pioniersplekken op het platteland is dat een pioniersplek als een concurrent van de dorpskerk kan worden beschouwd, omdat (jonge) mensen daar naartoe trekken, terwijl de dorpskerk de menskracht hard nodig heeft om door te gaan. Dat maakt de kans groot dat dorpskerk en pioniersplek tegenover elkaar komen te staan (Van Hierden et.al. 2018, 3). De vorm en de manier waarop pioniersplek en dorpskerk functioneren verschillen weliswaar, maar er zijn ook opvallende parallellen. In veel gevallen is de omvang vergelijkbaar: geloofsgemeenschappen van 30-40 mensen. Zowel 
pioniersplekken als dorpskerken zijn voortdurend bezig het wiel uit te vinden, nieuwe wegen op oude gronden te zoeken, kerk te zijn in een veranderende context (www.lerenpionieren.nl; www.dorpskerken.nl). Dat betekent dat pioniersplek en dorpskerk in de kern met een vergelijkbare zoektocht bezig zijn. Vanuit pioniersplekken wordt de vraag gesteld om een volwaardige en zelfstandige kerkplek te worden: zijn wij 'al' kerk (De Reuver \& Vellekoop 2019)? In dorpskerken speelt de spiegelbeeldige vraag: zijn we 'nog' kerk (Lichter verkend 2019)? Maar in beide gevallen draait het dus om de vraag: wat is nodig om voluit en volwaardig kerk te zijn? Hierin bespeur ik misschien wel vooral een vraag en verlangen naar wederzijdse erkenning.

In de derde plaats neem ik waar dat er 'dorpskerken 2.0' ontstaan, vormen van kerk-zijn die traditionele confessionele en/of geografische grenzen overschrijden. Ten eerste doet zich hier en daar de situatie voor dat waar verschillende kerkgemeenschappen zo klein geworden zijn, dat ze niet meer zelfstandig kunnen bestaan, ook kerkmuren afbrokkelen en christenen in een dorp elkaar opzoeken bij een kerstdienst of dorpsfeest. Op die manier kan de dorps-kerk-gemeenschap herontdekt worden, waar kerkgrenzen overstegen worden. Dat is een bijzondere ontwikkeling in dorpen waar de sociale verbanden lange tijd bepaald werden door wie bij welke kerk behoorde. Daardoor was de kerk decennialang een bron van sociale segregatie. Dat is juist een van de redenen waarom dorpsbewoners soms sceptisch staan tegenover de kerk. Waar nu kerkgrenzen overstegen worden, wordt vaak ook het onderscheid tussen binnen en buiten de kerk overwonnen. Dat gebeurde bijvoorbeeld in Overschild, toen een paar jaar geleden dorpsbewoners van verschillende denominaties de handen ineen sloegen om samen een kerstnachtdienst te organiseren. De kerk zat vol, met mensen van verschillende (niet) kerkelijke achtergrond en ze waren geraakt dat ze nu eens in hun eigen dorp naar de kerk konden (Gelderloos 2018a, 236-238).

Dorpskerk 2.0 kan ook een netwerkkerk zijn van mensen uit verschillende dorpen die op verschillende plekken samenkomen om te vieren, van gedachten te wisselen en samen te zijn. Tijdens mijn onderzoek in Groningen ontmoette ik vanuit de kerk in Noordbroek een groep van vrijzinnig protestanten die een keer per maand een dienst hebben in Scheemda, soms een dienst in Noordbroek of Hellum bezoeken en een gespreksgroep hebben. De mensen wonen verspreid in de regio, de verbondenheid met de mensen en de liturgie bindt hen samen. De groep is ontstaan nadat de hervormde gemeente Scheemda fuseerde met de gereformeerde kerk van Scheemda, vanuit een behoefte vrijzinnige vieringen te blijven houden. Hoewel de vieringen voor de bezoekers voelen als hun kerk, geven ze ook aan dat het officieel niet meer een 
kerk is. Het kerkgebouw is nu eigendom van de Stichting Oude Groninger Kerken en de groep huurt de kerk voor hun maandelijkse vieringen. Er is geen kerkenraad, er is geen actieve diaconie. Ze voelen zich niet in staat om een actieve rol in het dorpsleven van Scheemda te spelen, omdat de groep te klein is en niet iedereen in het dorp woont. Maar de pastor die betrokken is bij de groep denkt dat je de groep wel een kerk-plek zou kunnen noemen:

\begin{abstract}
"Omdat ze bij elkaar komen om samen te vieren en dan de belangrijkste bron de Bijbel is. En ze geloven allemaal in, eigenlijk wel in God, hoe je hem ook verwoordt of noemt of bekijkt. En ik vind dat dus kerk. En wat ze doen voor elkaar en met elkaar, vind ik ook kerk. Want daarin zijn ze wel pastoraal, diaconaal. Ze kijken naar elkaar om, ze kennen elkaar ook en ze gaan op bezoek bij iemand die ziek is of ze halen elkaar op als er activiteiten zijn of vervoer. En dat is dan wel een aardige club. Eén keer per jaar eten ze ook met elkaar en dan zitten daar toch zeker 20 mensen, 25 misschien wel." (Gelderloos 2018a, 225-228).
\end{abstract}

De vraag komt op of deze netwerkgroep een voorafschaduwing is van de kerk van de toekomst. Het laat zien dat het mogelijk is om een geloofsgemeenschap te vormen over grotere afstand, zonder de last van beheer van kerkgebouw, kerkelijke structuren en middelen. Dat maakt de organisatie licht. Maar omdat de - veelal oudere - leden van de groepen niet bij elkaar om de hoek wonen, is het lastig om in het dagelijkse leven direct elkaar te helpen. Daarnaast blijkt het lastig om vorm te geven aan de verbondenheid met de directe context van het dorp. Misschien is dat een van de redenen dat een aantal mensen in de groep ook betrokken is bij andere kerkgemeenschappen - dichter bij huis.

Ten slotte blijkt uit mijn onderzoek dat het religieuze dorpsleven breder is dan het kerkelijk leven. Er blijken plekken te zijn van reflectie, ritueel en bezinning waarin het alledaagse overstegen wordt waardoor verschillende groepen samengebonden worden. Religieuze functies verplaatsen zich naar andere domeinen van de samenleving. Zo ontstaan (tijdelijke) alternatieve kerkplekken, die soms een link hebben met de dorpskerk, maar soms ook niet. Er zijn vieringen en weekopeningen op (openbare) basisscholen, er vinden herdenkingsmomenten plaats rond 4 mei en in november, als alle overleden dorpsbewoners herdacht worden. Er zijn kunstprojecten waarin kerk en cultuur bij elkaar worden gebracht tijdens Feest van de Geest, concerten en toneeluitvoeringen. De godsdienstsocioloog Nancy Ammerman gebruikt het begrip sacred consciousness om het religieuze aan te kunnen wijzen op plekken die ook seculier zijn. Op het moment dat er op een openbare basisschool 
adventsvieringen worden gehouden kan dat beschouwd worden als een plek waar 'sacred consciousness socially is created and sustained' (Ammerman 2014, 298). Dan blijkt ook dat door de ontkerkelijking er steeds minder van die plekken zijn waar met terugkerende regelmaat in gemeenschapsverband dit besef van het heilige wordt aangesproken.

Hier komen vergelijkbare vragen op, zoals eerder rondom pioniersplekken en dorpskerken: wat is al kerk en wat is nog kerk? Is er een grens aan wat nog kerk genoemd kan worden? In het Brabants Lierop worden Koepelkerkconcerten gehouden op Goede Vrijdag en Allerzielen. Deze concerten worden georganiseerd omdat dorpsbewoners willen dat het kerkgebouw als religieus centrum in gebruik blijft. Er wordt zowel kerkelijke als seculiere muziek gespeeld, er zijn momenten van samenzang en een van de pastores houdt een meditatie over het thema. In strikte zin is het geen kerkdienst, er is geen liturgie. In hoeverre kan dit kerk genoemd worden?

De vraag kwam ook op na de kerstnachtviering in de dorpskerk van Hellum die georganiseerd was door de kerk, samen met de dorpsvereniging, het dorpskoor en de school. Er was een levende kerststal opgebouwd met ezels en schapen, een blinde herder, engelen, wijzen, Maria en Jozef. Er werden veel kerstliederen gezongen, de predikant probeerde de taal laagdrempelig te houden. Op het moment dat er na de overweging een gebed werd uitgesproken werd dat tegelijkertijd benoemd als een tekst ter meditatie. God werd met de grootste omzichtigheid benaderd: 'Datgene wat boven ons uitstijgt, wat sommigen misschien wel God noemen'. Enerzijds ontbreekt er op deze momenten een cruciaal element. Er wordt wel gesproken over God, maar niet tot God. Toch kunnen mensen op dit soort momenten wel iets van God ervaren. Wanneer ze zeggen dat een Goede Vrijdag-concert voor hen Pasen is. Wanneer ouders met hun kinderen naar de kerstviering op school gaan - dat is waar ze kerst beleven en vieren. En wanneer een toevallige bezoeker in Hellum die nog nooit in de kerk is geweest en moeite heeft met het leven de hele avond uitroept wat een mooie avond het is en geraakt is door de saamhorigheid. Dit soort momenten laten zien dat mensen een behoefte hebben aan gemeenschappelijk ritueel, bezinning, heilige plaatsen, herdenken en zingen (Gelderloos 2018a, 238-242).

Kerk-zijn op het platteland is dus dynamisch en veelvormig en sterk in beweging. De Britse theoloog Pete Ward wijst op het fenomeen van de liquid church, een fluide kerk, naast de traditionele solid church met een kerkdienst op zondagochtend in een kerkgebouw. Het begrip liquid church maakt het mogelijk om ook andere vormen van kerk-zijn te herkennen (Ward 2002). Dorpskerken 
zijn er in allerlei soorten en maten: 'gewone' dorpskerken, samenwerkingsgemeenten, identiteitsgemeenten met een regionale aantrekkingskracht en netwerkkerken. Daarnaast ontstaan er nieuwe vormen van kerk-zijn, variërend van pioniersplekken tot alternatieve ad-hoc kerkplekken. De fluiditeit van kerk-zijn wordt nog versterkt doordat mensen zich bij meerdere kerkplekken tegelijk betrokken kunnen voelen.

\section{Kerk-zijn op het platteland}

In de voorgaande twee paragrafen hebben we gezien hoe ontwikkelingen rond kerk-zijn op het platteland twee clusters van vragen oproepen die in elkaar grijpen. In deze paragraaf wil ik resumeren welke vragen de ontwikkelingen oproepen om vervolgens te kijken hoe theoretische inzichten van onder anderen Pete Ward en Michael Moynagh kunnen helpen om deze vragen beter te doorgronden. Het eerste cluster concentreert zich rond de vraag: hoe geef je vorm aan kerk-zijn op het platteland in tijden van ontkerkelijking, toenemende mobiliteit en samenwerking? Hoe zijn we kerk voor het hele dorp als er meerdere kerkgenootschappen zijn, is er interkerkelijke samenwerking mogelijk? Hoe zijn we kerk in alle dorpen, als de kerkgemeenschap meerdere dorpen omvat? Zijn er andere manieren om zichtbaar aanwezig te zijn, als er nauwelijks kerkdiensten zijn, het kerkgebouw verkocht is, en de predikant voor veel dorpsbewoners een onbekende is? Kunnen er ook activiteiten in het dorpshuis plaatsvinden? Is er iemand in het dorp die aanspreekbaar is vanuit de kerk? Hoe zijn we kerk in het dorp voor de kerkgangers die uitvliegen naar alle windstreken, kunnen we een gemeenschap van christenen vormen? Hoe zijn we kerk in het dorp als $80 \%$ van de kerkgangers elders woont en zij elkaar door de week niet tegenkomen in het dorpshuis, op het schoolplein of in de winkel?

Naast de vraag hoe kunnen we vorm geven aan het kerk-zijn voor en van het hele dorp c.q. alle dorpen, is er een tweede ecclesiologische vraag aan te wijzen. Eigenlijk is dat de basale vraag naar wat is kerk, wanneer kunnen we spreken van een kerkplek? Deze vraag wordt op verschillende manieren gesteld. Enerzijds zijn er pioniersplekken die zich willen ontwikkelen tot volwaardige kerkplekken en de vraag stellen: zijn wij al kerk? Anderzijds zijn er kleine (dorps)kerken die kleiner worden en zich afvragen wanneer de laatste lidmaat het licht uitdoet: zijn wij nog kerk? Het gaat hier om een spiegelbeeldige vraag naar de kern van kerk-zijn. Daarnaast speelt de vraag ook waar religie zich verplaatst naar andere domeinen en waar - voor even - alterna- 
tieve kerkplekken ontstaan. Plekken zoals op scholen, in concerten en in de zorg waar sporen van de christelijke traditie aanwijsbaar zijn. In hoeverre is hier nog of al sprake van kerk? In al die vragen zit de aanname verscholen dat er ergens een overgang moet zijn waar nog wel sprake is van kerk en waar niet meer. Het blijkt alleen erg lastig, zo niet onmogelijk, om die grens precies aan te wijzen. Vooral ook omdat die grens voortdurend verschuift.

Deze twee clusters van vragen hebben alles met elkaar te maken. De vragen rondom kerk-zijn in het dorp laten zien dat kerk-zijn op het platteland veelvormig is. Er is een mozaïek van kerkplekken en die kerkplekken geven op verschillende manieren uiting aan kerk-zijn en functioneren op verschillende manieren. Die veelvormigheid roept als vanzelf de vraag op wat wel en wat niet als kerk beschouwd kan worden. Het moge duidelijk zijn dat het vanwege de grote diversiteit en contextuele verschillen niet mogelijk is om een pasklaar antwoord te geven op de vraag hoe anno 2020 kerk te zijn op het platteland. Wel is het mogelijk om een aantal denkrichtingen aan te geven die helpen om voorbij twee tegenstellingen te komen. Ten eerste de neiging om lokaal en regionaal kerk-zijn tegenover elkaar te plaatsen. Ten tweede de valse tegenstelling tussen nieuwe en oude kerkplekken in de vraag of er al of nog sprake is van kerk.

Vaak wordt gezegd dat de kerk een plek moet zijn van leren, vieren en dienen. Dan wordt vooral gekeken naar wat de kerk doet en niet wat kerk is. De Britse theoloog Michael Moynagh heeft een andere benadering die aanknopingspunten biedt voor beide clusters van vragen. Hij zegt dat een kerkplek kerk genoemd kan worden als er sprake is van vier relaties. Ten eerste de relatie met boven, met God. Ten tweede noemt hij de relatie met binnen: de gemeenschap van mensen in een lokale geloofsgemeenschap. Ten derde de relatie met buiten: in liefde, zorg en betrokkenheid bij de wereld. Ten slotte de relatie tussen kerkplekken: de geloofsgemeenschap als deel van een groter geheel - verbonden met de kerk van alle tijden en alle plaatsen. Volgens Moynagh zijn de praktijken van leren, vieren en dienen niet onbelangrijk, maar de praktijken zijn niet doel op zich, maar dienen om de vier relaties die kerk tot kerk maken in stand te houden. Daarom moeten praktijken zich ook door de tijd heen ontwikkelen en is er in de kerk een voortdurende discussie over hoe vorm te geven aan kerk zijn (Moynagh 2012, 106, 110). Steeds weer moeten nieuwe wegen op oude gronden worden gevonden.

Langs de lijnen van de vier relaties wil ik een aantal denkrichtingen verkennen. Allereerst de relatie met boven - met God. In dorpskerken is die relatie in bijbelverhalen, liederen en gebeden vaak duidelijk aanwezig. Op alternatieve kerkplekken wordt God soms wel genoemd, soms omfloerst 
benoemd en soms vermeden. Dat roept de vraag op in hoeverre kunnen er sporen van God aangewezen worden in deze praktijken van ritueel, bezinning, gemeenschap? Hoewel niet alle praktijken expliciet plaatsvinden in de naam van God, hebben ze wel religieuze betekenis. Ze hebben een ander karakter dan een bijeenkomst in het dorpshuis. In bijna alle gevallen zijn er wel verwijzingen naar de christelijke traditie in muziek, verhalen of de plaats van het kerkgebouw. In hoeverre mensen zich aan deze christelijke traditie verbinden wordt aan het individu overgelaten. De bijeenkomsten zijn erop gericht om gemeenschapsbanden aan te halen en verschillen in kerkelijke achtergrond te overbruggen door te verwijzen naar gedeelde verhalen en waarden. En zo doet zich een paradox voor dat enerzijds door de ontkerkelijking het religieus analfabetisme groeit, maar dat anderzijds religieuze praktijken zich verplaatsen naar andere domeinen van de samenleving.

Jürgen Moltmann spreekt in dit verband over de Geest die opduikt buiten de kerk (Moltmann 1992). Of zoals een pastor in verzorgingshuis opmerkt:

"Ik denk dat mensen iets alternatiefs zoeken en ze vinden het toch niet meer in de kerk. De kerk in de oude vorm gaat verdwijnen, omdat het zo los van het leven staat. Ik denk dat er veel gebeurt tussen mensen, mensen die ook samenkomen. Mensen die samen een boek bespreken, die in de Schrift lezen die samen daarover praten. Dus ik denk dat er heel veel gebeurt." (Gelderloos 2018a, 295)

Ward bespeurt hierin een spiritueel verlangen en zoektocht naar betekenis en een liquid church is zich bewust van dit verlangen en zoeken naar God (Ward 2002, 72-75). Dat betekent dat (dorps)kerken er goed aan doen om alert te zijn op deze praktijken en signalen en de behoeften die hieraan ten grondslag liggen. Omdat daardoor aanknopingspunten worden geboden om contact te leggen met de bredere dorpsgemeenschap. Vanuit de theologische overtuiging dat Christus is te vinden in de wereld. Volgens Moynagh is het een misvatting dat de kerk Christus in de wereld brengt, het is juist andersom God komt vanuit de wereld in de kerk (Moynagh 2012, 101-102). Tegelijkertijd is de kerk ook een plek om de wereld te bevragen en er kritisch tegenover te zijn.

Om sporen van God in het dorp te ontdekken en te bevragen is het nodig om de blik naar buiten te richten. Maar dat is niet eenvoudig. De organisatie van het kerkelijk leven neemt een groot deel van de beschikbare tijd en energie van voorgangers en kerkgangers in beslag (De Roest 2015, 64; Gibson 2010, 122). Een overlevingsmodus beperkt vaak het zicht op nieuwe mogelijkheden (Langrish 2004, 40-41). De krimp en ontkerkelijking hebben de blik naar binnen gericht. Dat brengt ons bij de relatie binnen de gemeenschap. Vaak is in 
dorpskerken de onderlinge betrokkenheid in de kern van de gemeenschap groot. Maar dat heeft ook een keerzijde. Moynagh wijst erop dat in veel traditionele kerken mensen op zondag samenkomen en een gemeenschap vormen, maar het geloof beleven en uitleven in het dagelijks leven gebeurt vaak individueel. Mensen zijn betrokken bij diverse groepen en gemeenschappen door de week, daarin nemen ze deel aan de gemeenschap met Christus, maar daarin zijn ze niet zichtbaar onderdeel van de kerk. Dat maakt zoals we hierboven hebben gezien de kerk als gemeenschap van gelovigen wat onzichtbaar. Wanneer kerkgangers verspreid wonen, wordt het lastiger voor een kerkgemeenschap om een specifieke context te dienen en een gedeelde missie vorm en inhoud te geven (Moynagh 2012, 139, 143). Dat betekent dat in tijden van samenwerking en regionalisering gemeenschapsvorming extra aandacht vraagt. Als kerkgemeenschappen formeel fuseren, is er nog niet direct een nieuwe geloofsgemeenschap gevormd. Dat vraagt tijd, geduld en aandacht, terwijl er tegelijkertijd ook aandacht en ruimte nodig is voor contact met de dorpsgemeenschappen.

Dat vraagt om een perspectiefwisseling waarin de aandacht verlegd wordt van binnen naar buiten, de derde relatie. We hebben gezien dat in het beleid rond dorpskerken jarenlang gezocht is naar het ontwerpen van een organisatiestructuur om de institutionele kerk te kunnen laten voortbestaan. Veel aandacht gaat naar organisatie, waarbij soms voorbij gegaan wordt aan de vraag hoe kerk te zijn in een gedifferentieerd en geseculariseerde samenleving. Auteurs als De Loor wijzen erop dat apathie in dorpskerken het grootste probleem is: mensen zijn bezorgd over de krimp, maar weten niet wat de plaats van de kerk in een moderne plattelandssamenleving zou kunnen zijn. Er is sprake van kerkelijke verlegenheid. Andreas von Maltzahn bespeurt bij kerkgemeenschappen achter de dagelijkse zorgen een fundamentele crisis waardoor het moeilijk is om over geloof te spreken: een gedeeld zelfverstaan van waar de kerk voor staat is verloren gegaan. Hij vraagt zich af of in deze onzekerheid sporen van God gevonden kunnen worden en of de kerk zich nog steeds in het spoor van God begeeft (Von Maltzahn 2016, 185-187). Een van de problemen die hij ziet is dat mensen verlangen naar het verleden, zoals de Israëlieten in Babylon terug verlangden naar hun leven in Jeruzalem. Dat is in zijn ogen een heilloze weg: kerken zouden niet zozeer moeten streven naar zelfbehoud, maar naar wat de dorpsgemeenschap nodig heeft.

Als kerkgemeenschappen zich richten op wat er speelt in het dorp, zien welke vragen en behoeften daar leven en oog hebben voor het religieuze dorpsleven, verdwijnen vragen over voortbestaan en organisatie naar de achtergrond. Moynagh wijst er in navolging van Moltmann op dat maatschappe- 
lijke organisaties en belangengroepen kerken kunnen wijzen op ecologische en maatschappelijke vraagstukken en het bewustzijn in geloofsgemeenschappen kunnen aanwakkeren (Moltmann 1992, 242). Als kerken kijken naar de leefbaarheidsvraagstukken die spelen in de rurale context en hoe mensen persoonlijk worden geraakt door maatschappelijke ontwikkelingen op het gebied van zorg, werk, onderwijs, mobiliteit en voorzieningen, dan komt onvermijdelijk de vraag op hoe hierin als kerk een rol van betekenis te spelen en kunnen zich de contouren van een contextuele rurale theologie gaan aftekenen. De bundel Faith and the future of the countryside wijst op de noodzaak "to reinforce the commitment of churches to a meaningful and engaged presence in rural communities in a way which undergirds mission and ministry" (Smith \& Hopkinson 2012, xiii).

Zo komen we bij de relatie tussen kerken. Vanuit dit soort processen kunnen samenwerkingsverbanden ontstaan tussen kerken en/of niet-kerkelijke organisaties, die voortkomen uit een gedeelde zorg of een gedeeld verlangen, die niet direct het eigen voortbestaan aangaan. Dat biedt een andere basis van samenwerking dan samenwerken vanuit een organisatorische noodzaak en overlevingsmodus. Deze vormen zijn soms onvermijdelijk om kerkelijk present te blijven in de regio, maar hebben het risico in zich dat het de naar binnen gerichte blik versterkt. Naar mijn idee ontkomen kerken er niet aan om te schaken op meerdere borden, zowel lokaal als regionaal. Het zijn verschillende vormen van kerk-zijn die op verschillende manieren functioneren. Het model van verbondenheid van David Walker maakt dit inzichtelijk. Een regionale kerk wordt in stand gehouden door de verbondenheid die mensen voelen met de gemeenschap, de band die ze voelen met individuele kerkleden en met regelmatig terugkerende activiteiten, zoals zangmiddagen, gespreksgroepen en kerkdiensten. Voor regionale kerknetwerken is lokale betrokkenheid en samenwerking met andere organisaties in het dorp niet het primaire aandachtspunt. Zoals we zagen in Scheemda waar de groep bij elkaar gehouden wordt door de maandelijkse vieringen. Voor lokaal kerk-zijn zijn juist het kerkgebouw en de betrokkenheid bij evenementen bepalend. In dorpsmomenten en de plaats van het kerkgebouw kunnen kerk- en dorpsgemeenschap een aanleiding vinden om samen op te trekken. Dat betekent dat regionaal en lokaal kerk-zijn elkaar kunnen aanvullen en elkaar in stand kunnen houden.

Volgens Moynagh kunnen nieuwe en oude vormen van kerk-zijn elkaar aanvullen en over en weer ondersteunen. Doordat hun aanbod verschillend is, kunnen ze verschillende doelgroepen aanspreken en in verschillende behoeften voorzien. Op die manier kan de last van dorpskerken ook verlicht worden, als andere kerkplekken taken overnemen. Dat kan echter alleen als er "een 
breed gedeelde visie bestaat op wat kerkplekken op een dieper niveau met elkaar verbindt" (Van Hierden 2018, 4). Daarom, meen ik, is het van groot belang om de verbondenheid tussen kerkplekken te vergroten. Niet vanuit organisatorische overwegingen, maar vanuit een over en weer herkennen en erkennen verbonden te zijn in de Geest van God en door een gedeeld verlangen naar vrede, gerechtigheid, gemeenschap.

\section{Concluderende opmerkingen}

De afgelopen decennia is de relatie tussen kerk en dorp ingrijpend veranderd door ontkerkelijking, processen van samenwerking en toenemende mobiliteit. Er is echter weinig reflectie geweest op de ecclesiologische gevolgen van deze ontwikkelingen. Dat heeft er soms toe geleid dat kerken een naar binnen gerichte blik hebben ontwikkeld, minder zichtbaar en minder toegankelijk zijn en er meer gevraagd wordt van de betrokkenheid van mensen. Een kleine groep kerkgangers kan bevangen worden door het gevoel dat de toekomst van de kerk van hen afhangt. Als de vraag hoe te overleven als kerk het kerkelijk leven gaat domineren, bestaat het risico dat mensen weinig meer ervaren van wat een geloofsgemeenschap zou moeten zijn. Een plek waar ruimte wordt geschapen voor geloof en zingeving, zorg en aandacht, kyrie en gloria en voor vragen wat kerk-zijn aan het begin van de $21^{\mathrm{e}}$ eeuw in een plattelandscontext betekent (Gibson 2010, 122; Langrish 2004, 40-41). De laatste jaren is er een 'turn to the local' gaande en groeit de aandacht voor hoe kerken vorm kunnen geven aan kerkelijke presentie in het dorp.

Zo hebben diverse ontwikkelingen geleid tot het ontstaan van een mozaiek van kerkplekken. Mensen kunnen zich op verschillende manieren verbonden voelen met de kerk, dat maakt dat de kring van mensen die iets met de kerk hebben wijder is dan de groep mensen die op zondagochtend in de kerk zit. Dat betekent ook dat mensen zich met meerdere kerken tegelijk verbonden kunnen voelen. Ten tweede ontwikkelen zich nieuwe vormen van kerk-zijn op pioniersplekken. Tegelijkertijd ontstaan er ook dorpskerken 2.0, in dorpen waar mensen van verschillende (niet) kerkelijke achtergrond elkaar opzoeken. Daarnaast ontwikkelen zich regiogemeenten die vanwege een bepaalde confessionele of liturgische identiteit mensen uit de wijde omgeving trekken. Ten slotte zijn er op verschillende plaatsen alternatieve kerkplekken aan te wijzen waar sacred consciousness in gemeenschapsverband wordt gevormd.

Kerk-zijn op het platteland is veelvormig en dynamisch, Pete Ward spreekt in dit verband over liquid church. Dit roept enerzijds vragen op over hoe kun 
je op een goede manier kerk-zijn op het dorp, als er zowel op regionaal als op lokaal niveau geopereerd moet worden. Anderzijds is er de vraag wat is kerk, wanneer kunnen we spreken van een kerk-plek? Die vraag speelt zowel waar kerk dreigt te verdwijnen, als waar nieuwe vormen van kerk-zijn verschijnen. Centraal in deze vraag staat het relationele aspect. Dat maakt de ecclesiologie van Michael Moynagh zeer geschikt om deze vragen nader te bekijken. Volgens Moynagh is er sprake van kerk waar vier relaties aanwezig zijn: met God, met elkaar als gemeenschap, met de wereld en met de kerk van alle tijden en alle plaatsen. Niet op alle kerkplekken zijn deze relaties in gelijke mate aanwezig, maar dat betekent dat verschillende kerkplekken elkaar kunnen aanvullen doordat ze op verschillende manieren functioneren, verschillende doelgroepen aanspreken en verschillende talen spreken. Wanneer kerken en dorpen er in slagen om met andere ogen naar kerk-zijn, leven en geloven te kijken kan een perspectiefwisseling op gang komen, waardoor organisatorische vraagstukken en verouderde kerkbeelden naar de achtergrond kunnen verdwijnen.

\section{Noten}

1 Interview met Rinie Meihuizen, Doopsgezind predikant Groningen, 13 juni 2016.

\section{Literatuur}

Akker, Jaap van den (2003),

Tweestromenland: tussen dorp en streek, in: Samenwerking in de regio,Toer.

Ammerman, N.T. (2014),

Sacred Stories: Spiritual Tribes, Finding Religion in Everyday Life, New York: Oxford University Press.

Beekman, Wim, (2011),

Leve de dorpskerk, Verslag van een studie naar de mogelijkheden en beperkingen van kleine kerkelijke gemeenten in kleine dorpsgemeenschappen.

Bennett, Bill (2007),

The pastoral imperative in rural ministry: helping rural people discern God's activity in their midst, in: Rural Theology, 5 (2), 75-84.

Broos, Katinka, (1998),

Samen gemeenschap zijn, in: Kleine kerken, Themanummer Missionaire Gemeente. Brouwer, Rein, et al., (2007),

Levend lichaam, dynamiek van christelijke geloofsgemeenschappen in Nederland, Utrecht: Kok. 
Bruijkers, Anja (2003),

Regionalisering: van gemeente naar gemeenschap, in: Samenwerking in de regio, Toer.

De hand aan de ploeg (2009),

Definitief rapport van de Stuurgroep "Werk in de wijngaard", Aangeboden aan de generale synode van de Protestantse Kerk in Nederland door het moderamen, april 2009 .

Gelderloos, J.K. (2018),

Meaningful in the Margins, Churches and Quality of Life in the Dutch Countryside, Groningen.

Gelderloos, J.K. (2018),

Sporen van God in het dorp, Nieuwe perspectieven voor kerken op het platteland, Zoetermeer: Boekencentrum.

Gibson, Tim (2010),

Church and Countryside: Insights from Rural Theology, Norwich: SCM Press.

Gräb, Wilhelm (2010),

The Transformation of Religious Culture within Modern Societies: From Secularization to Postsecularism in: Molendijk, Arie, Justin Beaumont \& Christoph Jedan, Exploring the Post Secular: The Religious, the Political and the Urban, Leiden: Brill, 113-129.

Hendriks, J., et al. (red.) (1971),

Hoe komen kerken tot nauwere samenwerking?, Utrecht: Bureau Generale Deputaten kerkopbouw van de Gereformeerde kerken in Nederland.

Hierden, B. van (2010),

Samen werken, samen kerken? Een kwalitatieve studie naar de betekenis van regionale samenwerking voor plaatselijke protestantse gemeenten, (Master thesis, Universiteit Utrecht).

Hierden, Nadine van, et al. (2018),

Over speelruimte en spanning, praktijkonderzoek naar de relatie tussen bestaande en nieuwe kerkplekken, Utrecht: Dienstenorganisatie van de Protestantse Kerk in Nederland, Hoogterp, Gerben (1998),

De streekgemeente, nood en deugd in: Kleine kerken, Themanummer Missionaire Gemeente, 18 (4).

Jong, Gert de (2008),

Doen alsof er niets is, sociologische gevalsstudie over een kerkelijke gemeente als dynamische configuratie, Wageningen: Pronsen \& Looyen BV.

Generale synode (2016)

Kerk 2025: Een stap verder,

Klein en dapper (2016).

Kerkinformatie (243). 
Langrish, L. (2004),

Dynamics of Community, in: Martineau, Jeremy, Leslie J. Francis \& Peter Francis (eds), Changing Rural Life: A Christian Response to Key Rural Issues, Norwich, Canterbury Press, 21-43.

Leene, G.J.F. (1969),

Het probleem van de kleine kerken, een sociologisch onderzoek naar de houding van de gereformeerden op Noord-Beveland ten aanzien van kerkelijke schaalvergroting, Middelburg: Stichting Gereformeerd Sociaal Centrum voor Zeeland.

Lichter verkend (2019), (Tussenrapportage werkgroep kleine gemeenten lichter).

Loor, H.D. de (1963),

De kerk en het moderne platteland, Moeilijkheden en mogelijkheden voor de kerk op het platteland, Den Haag: Boekencentrum.

Maltzahn, Andreas von (2016),

Weniger ist anders, Kirche und Gemeinden in ländlichen Räumen, Theologische Deutungen und praktische Perspektiven, in: Borck, Sebastian, Astrid Giebel \& Anke Homann (Hg), Wechselwirkungen im Gemeinwesen: Kirchlich-diakonische Diskurse in Norddeutschland, Berlin: Wichern-Verlag, 186-198.

Mesman, Max \& Janet van Dijk (red.) (2011),

Klein en vitaal: aanstekelijke verhalen van kleine gemeenten, Utrecht: Dienstenorganisatie van de Protestantse Kerk in Nederland.

Moltmann, Jürgen (1992),

The Spirit of Life: A Universal Affirmation, London: SCM Press.

Moynagh, Michael (2012),

Church for every context: an introduction to theology and practice, London: SCM Press. Plaisier, Arjan (2016),

Kerk 2025, Waar een Woord is, is een weg, Utrecht: Protestantse Kerk in Nederland.

Ploeger, Albert K. \& Joke J. Ploeger-Grotegoed (2001),

De gemeente en haar verlangen, Van praktische theologie naar de geloofspraktijk van de gemeenteleden, Kampen: Kok, Kampen.

Reuver, René de \& Martijn Vellekoop (2019),

Mozaïek van kerkplekken, over verbinding tussen bestaande en nieuwe vormen van kerkzijn, Utrecht, Dienstenorganisatie van de Protestantse Kerk in Nederland.

Rienksma, Tea (2003),

Samenwerking om eigen kernen te revitaliseren, in: Samenwerking in de regio, Toer.

Roest, Henk de \& Sake Stoppels (2015),

Terug naar de kern?, in: Handelingen, Tijdschrift voor praktische theologie en religiewetenschap: Missionair kerk-zijn in het dorp, (2), 62-69.

Russell, Anthony (1986),

The Country Parish, London, SPCK. 
Sennema, D.S. (1959),

Kerkelijkheid en buitenkerkelijkheid in een Noord-Groningse gemeente, Groningen: Sociologisch Instituut Rijksuniversiteit Groningen.

Smith, Alan \& Jill Hopkinson (2012),

Faith and the Future of the Countryside, Pastoral and Theological Perspectives on Rural Sustainability, Norwich: Canterbury Press,

Staverman, M. (1954),

Buitenkerkelijkheid in Friesland, Assen: Van Gorcum.

Stegeren, K.L. van (1966),

De kerk in het dorp, op zoek naar een organisatievorm voor de kleine gereformeerde kerken op het platteland, [s.1., s.n.].

Stoppels, Sake (2017),

Notitie 'huisgemeente'.

Valstar, Peet (2004),

Kansen voor de kleine dorpskerk, Utrecht: Dienstenorganisatie Protestantse Kerk in Nederland.

Veer, Trieneke van der (1999),

Kerk op de terp, in: Konvooi: Werkschrift voor kerk en samenleving, 32 (3), 16-18.

Vos, Dick (2011),

Samenwerking: noodzaak én recept, in: Woord en Dienst, 8-10.

Ward, Pete (2002),

Liquid Church, Carlisle: Paternoster Press.

Weiland, A. (1956),

Geloof en ongeloof in een Noord-Hollandse polder. Een religiografie van de Beemster, Middenbeemster: Weiland, (Proefschrift Rijksuniversiteit Groningen).

\section{Graadpleegde weblocaties}

www.dorpskerken.nl, 7 december 2019 .

www.lerenpionieren.nl, 7 december 2019.

https://www.protestantsekerk.nl/thema/missionair-werk/faq/, 7 december 2019.

https://nijkleaster.frl/, 12 november 2019.

http://www.zinvolzijpe.nl/ 12 november 2019.

www.lerenpionieren.nl, 7 december 2019. 